\title{
Conceptualising COVID-19's impacts on household food security
}

\author{
Stephen Devereux ${ }^{1,2}$ (D) $\cdot$ Christophe Béné $^{3}$ (D) $\cdot$ John Hoddinott ${ }^{4}$ (I)
}

Received: 19 May 2020 / Accepted: 3 July 2020 / Published online: 14 July 2020

(C) International Society for Plant Pathology and Springer Nature B.V. 2020

\begin{abstract}
COVID-19 undermines food security both directly, by disrupting food systems, and indirectly, through the impacts of lockdowns on household incomes and physical access to food. COVID-19 and responses to the pandemic could undermine food production, processing and marketing, but the most concerning impacts are on the demand-side - economic and physical access to food. This paper identifies three complementary frameworks that can contribute to understanding these effects, which are expected to persist into the post-pandemic phase, after lockdowns are lifted. FAO's 'four pillars'- availability, access, stability and utilisation - and the 'food systems' approach both provide holistic frameworks for analysing food security. Sen's 'entitlement' approach is useful for disaggregating demand-side effects on household production-, labour-, trade- and transfer-based entitlements to food. Drawing on the strengths of each of these frameworks can enhance the understanding of the pandemic's impacts on food security, while also pinpointing areas for governments and other actors to intervene in the food system, to protect the food security of households left vulnerable by COVID-19 and public responses.
\end{abstract}

Keywords COVID-19 $\cdot$ Entitlement approach $\cdot$ Food systems $\cdot$ Four pillars $\cdot$ Household food security

\section{Introduction}

The COVID-19 pandemic has had major impacts on health across the globe. In response, governments have imposed a range of measures to contain the spread of the virus and 'flatten the curve'. These include social distancing, restrictions on mobility and temporary closure of most workplaces, generally known as a 'lockdown'. As of May 2020, COVID-19 has not directly affected food systems except through sporadic closures of food processing facilities in some countries due to infected workforces.

Stephen Devereux

s.devereux@ids.ac.uk

Christophe Béné

C.Bene@CGIAR.ORG

John Hoddinott

jfh246@cornell.edu

1 Centre for Social Protection, Institute of Development Studies (IDS), Brighton, UK

2 Centre of Excellence in Food Security, University of the Western Cape (UWC), Cape Town, South Africa

3 International Center for Tropical Agriculture (CIAT), Cali, Colombia

4 Cornell University, Ithaca, NY, USA
By contrast, the lockdown measures, while necessary to minimise loss of life, are creating significant economic stresses, with adverse consequences for food security and hunger.

Understanding how these consequences arise, and how best to respond, can be improved by drawing on conceptual frameworks commonly used in food security analysis. We consider three: FAO's 'four pillars' approach (FAO 2008); the 'food systems' approach as proposed by the UN Committee on World Food Security (HLPE 2017); and Sen's 'entitlement' approach (Sen 1981). We argue that analysing and alleviating the food security crisis that COVID-19 may create is best served by drawing on complementary aspects of these three frameworks, rather than privileging one over the others.

\section{Framework \#1: Four pillars}

Standard conceptual frameworks of food security, usually associated with the Food and Agriculture Organisation, have four pillars: availability, access, utilisation, and stability (FAO 2008). Availability corresponds broadly to food supply. Access refers to effective demand for food (economic access) and proximity of markets (physical access). Utilisation is about biological processing of food, which is partly related 
to dietary quality. Stability captures the dynamic aspect - as food is a daily necessity, being food secure requires stability in the other three pillars over time.

At the macro-level (i.e. global and national) COVID-19 has not yet compromised food availability to any noticeable extent. However, there are concerns about the observed behaviour of some countries to reduce their food exports to protect national supplies. Within countries, the agriculture sector has typically been exempted from lockdown restrictions, in order to ensure continuity of food production.

Food access is threatened by increases in food prices relative to wages or income. As of early June 2020, global food prices have shown relatively little change (World Bank 2020), partly because of good harvests of grains in key suppliers such as Brazil and partly because the fall in oil prices has reduced the cost of transporting food. In the longer term, there is more reason for concern. The 2008 food crisis was exacerbated by country prohibitions on food exports and should these resurface, it is possible that global food prices could again increase. Even if global prices remain relatively unchanged, there may well be localised price volatility. In a number of countries, including for example South Africa, retailers have profiteered from panic buying by raising prices of food excessively (Competition Commission 2020).

Stability of food availability and access is affected by COVID-19-related prohibitions on movement and the closure of informal food markets in order to achieve greater social distancing. These closures may not affect all foods equally perishable products such as fruits, vegetables and animal source foods could experience more stock-outs compared to storable products such as grains and vegetable oils.

For poor consumers, a forced shift to more expensive food outlets such as supermarkets, following the closure of open-air markets and a ban on street vendors, may disrupt food access further and reduce diet quality. In the medium-term, a prolonged reduction in access to preferred food and a shift to cheaper, less nutritious food could lead to deteriorating nutrition status.

\section{Framework \#2: Food systems}

A food system includes "all the elements (environment, people, inputs, processes, infrastructures, institutions, etc.) and activities that relate to the production, processing, distribution, preparation and consumption of food, and the output of these activities, including socio-economic and environmental outcomes" (HLPE 2017: 23). An in-depth system-based analysis of the food security impacts of COVID-19 would consider how it affects each element and each activity in a given country or local context. Adopting a food system lens is not, however, just about a holistic view and including all processes 'from farm to plate'. It is also about recognising the dynamic and inter-dependent nature of relations between the different components and actors in the system, including trade-offs and feedbacks (Ericksen 2008). As such, a particular strength of a food system approach is its recognition that a change in one component is likely to affect several others, sometimes with unintended detrimental consequences.

A further strength is that a food system approach incorporates considerations of all aspects of food value chains. Consider, for example, the potential impact of the pandemic on food production. Concerned about the adverse effects of COVID-19 on food security, most governments have exempted from national lockdowns workers engaged in agricultural production. As of June 2020, there are few reported cases of disruptions to food production (World Bank 2020). However, it is unclear whether this will continue to be the case. Some farmers and farm workers will become ill or die from COVID-19. Likewise, food production requires the use of inputs such as seeds and fertilisers. Access to these is susceptible to disruptions in international shipping, closure of land border crossings, and in-country restrictions on mobility. As planting seasons begin, farmers borrow money from financial institutions to acquire the working capital needed to purchase inputs. Where financial institutions have been closed, as is the case currently in Bangladesh, this may make it difficult to access the loans needed for these inputs.

Food production requires labour and even farms of modest size hire in workers at certain points during the crop production cycle. Access to hired labour may be disrupted either because prospective workers are unwilling to travel to work sites, or because prohibitions on movement mean that workers cannot travel or because strict enforcement of social distancing regulations restricts the number of workers who can work together. The food system lens brings together the myriad ways in which lockdowns may affect food production, even when exemptions for agricultural work are put in place.

Food markets are a second example. Most retail outlets are allowed to continue trading during the lockdown in most countries, and consumers are allowed to leave their homes to buy essential food and groceries. In localities where consumers purchase food through formal sector outlets (think supermarkets), this permits physical access to food to continue, though stock outs of specific foods may occur. However, restrictions on the size of crowds that can congregate have resulted in the closure of large, informal markets where the poor - particularly the urban poor - purchase a large part of their food. This becomes especially problematic for foods with limited shelf life - think fruit, vegetables, and animal source foods- with the result that these restrictions may adversely affect both the quantity and quality of foods available for consumption. In South Africa, after two weeks of intense public debate about the trade-off between health risks and hunger risks, informal food traders were allowed to apply for licenses to resume trading. 
Adopting a food system framework in the case of COVID19 helps therefore to better realise the complexity - and sometime very unstable nature - of the situation and the potential ripple effects that may pass through the entire food system once one component is affected (Béné 2020).

\section{Framework \#3: Entitlement approach}

Amartya Sen's 'entitlement approach', originally devised for the analysis of famines, is well-suited to assessing the food security consequences of COVID-19. Sen emphasised that food security is not simply a supply-side issue, it is fundamentally about who gets access to available food, which is about the distribution of wealth and resources. In 'Poverty and Famines', Sen (1981) identified four legal sources of food at the individual or household level: production-based, own-labour, trade-based, and transfer entitlement. Analysing these four categories reveals that the impact of COVID-19 on economic access to food is likely to be highly unequally distributed.

In rural areas, some farming households could lose access to food from their own production if they fall ill from COVID19 , or if they are unable to access labour and other inputs (e.g. fertiliser and seed), or if they lose access to markets to sell their produce, because of restrictions on trade and mobility.

Lockdowns undermine own-labour entitlements as they prevent people from engaging in wage work or operating businesses. For formally employed workers, especially in highincome countries, this is mitigated by either unemployment benefits or tailored government programmes that cover some proportion of workers' wages for the duration of the lockdown. Additionally, some workers are able to work from home via internet connections. By contrast, informal sector and selfemployed workers (e.g. daily labourers and street traders) do not have access to unemployment insurance schemes, they cannot be reached by pay protection schemes that target formal sector workers, and their work cannot be undertaken from home. For these households, the effect of the lockdown is analogous to breadwinners suddenly becoming disabled - their income drops to zero, they have no insurance, but they continue to consume food and household resources.

Private transfers of food or cash are also threatened by lockdowns. First, family members who work elsewhere and send remittances home have seen their own incomes collapse; the forcible repatriation of Ethiopian migrant workers in the Middle East being one example. Second, in some countries the financial infrastructure by which transfers are made (banks, Western Union offices and the like) have been closed making it physically difficult to send or collect such payments. In places where a 'hard lockdown' and social distancing are imposed, informal support and other forms of social capital at community level are further affected because neighbours and relatives are not allowed even to visit each other. Lockdowns have also affected the functioning of public transfer mechanisms, such as school meals which can no longer be provided in countries where schools have been closed.

\section{Summing up}

The three frameworks reviewed in this paper bring complementary insights to the analysis of food security impacts of COVID-19. The four pillars approach and the food systems approach provide an umbrella covering both supply and demand factors at the aggregate level. However, the four pillars approach gives greater salience to concerns regarding economic and physical access to food, the latter being potentially particularly important in environments where physical restrictions are imposed on movement and on open-air markets. The food systems approach, by contrast, emphasizes the fundamental interconnectedness of all elements of the food value chain, illuminating how shocks to one part of the system affect other parts. The entitlement approach disaggregates and nuances the demand-side drivers of access to food at household level and highlights the importance of particular mechanisms such as informal transfers and social capital which are not well addressed by the two other frameworks; however, it pays less attention to supply-side concerns. Thus, rather than privileging one approach over the others, drawing on the strengths of each can enhance an understanding both of the pandemic's impacts on food security and how best to respond.

The immediate need is to address the collapse of ownlabour and transfer based entitlements. In ordinary times, these are remedied through social protection interventions. During emergencies governments and donor agencies respond by providing humanitarian relief. A hybrid mechanism that links social welfare with humanitarian relief is 'shock-responsive social protection' (OPM 2017) - scaling up social protection mechanisms both horizontally (enrolling additional needy people) and vertically (paying additional benefits to social welfare recipients) is necessary to mitigate the collapse of own-labour and transfer based entitlements due to COVID-19.

However, this is unlikely to be sufficient. Food systems frameworks remind us that moving forward, protracted lockdowns risk creating disruptions to food production as well. In turn, these will lead to further deterioration of food entitlements through the loss of production-based entitlements or via adverse price movements and reductions in trade-based entitlements.

Lastly, using these frameworks collectively reminds us that government responses to COVID-19 will have adverse distributional consequences. Richer households in all countries are better protected from the economic consequences of lockdowns because they are able to continue working (that is, their own-labour entitlements are less adversely affected), they are 
less reliant on private transfers and they have better access to public transfer programmes such as wage protection schemes. Further, disruptions to food systems mean inconvenience line-ups to get into supermarkets - but do not mean markets are no longer physically accessible. By contrast, poorer households are more likely to be affected by the collapse of ownlabour and private-transfer entitlements, while being more vulnerable to the closure or their usual food supply outlets.

Authors' contributions Equal co-authors.

Funding information Devereux receives funding from the National Research Foundation of South Africa (Grant Number: 98411) and the Newton Fund, administered by the British Council.

Béné receives funds from the Food Systems for Healthier Diets flagship under the Agriculture for Health and Nutrition CGIAR research programme.

Data availability Not applicable.

Code availability Not applicable.

\section{Compliance with ethical standards}

Conflicts of interest/competing interests None.

\section{References}

Béné, C. (2020). Resilience of local food systems and links to food security - a review of some importantconcepts in the context of COVID19 and other shocks. Food Security (this issue).

Competition Commission South Africa (2020). Joint briefing to the portfolio committee on trade and industry and select committee on economic development, Small Business Development, Tourism, Employment and Labour: 19 May 2020. http://www.thedtic.gov. za/wp-content/uploads/Competition-Commission19-May-2020.pdf (Accessed 18 June 2020).

Ericksen, P. J. (2008). Conceptualizing food systems for global environmental change research. Global Environmental Change, 18, 234245.

FAO (2008). An introduction to the basic concepts of food security. Rome Food and Agriculture Organisation. www.fao.org/3/aal936e.pdf (Accessed 7 May 2020).

HLPE. (2017). Nutrition and Food Security. A report by the high level panel of experts on food security and nutrition. Rome: Committee on World Food Security.

Oxford Policy Management (OPM). (2017). Shock-responsive social protection systems research: Literature review. Oxford: Oxford Policy Management.

Sen, A. (1981). Poverty and famines. Oxford: Oxford University Press.

World Bank (2020). Brief: Food security and Covid-19. https://www. worldbank.org/en/topic/agriculture/brief/food-security-and-covid19 (Accessed 18 June 2020).

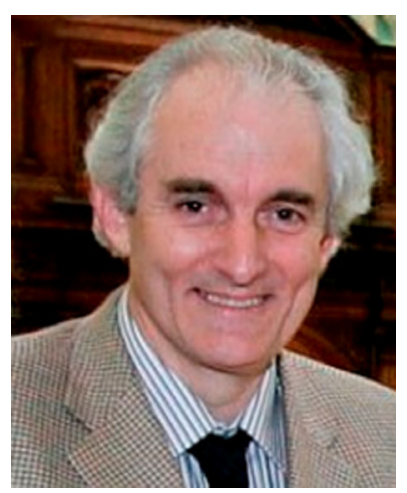

Stephen Devereux (corresponding author) is Co-Director of the Centre for Social Protection at the Institute of Development Studies in Brighton, UK; and NRFNewton Fund (SA-UK) Research Chair in Social Protection for Food Security, affiliated to the Centre of Excellence in Food Security at the University of the Western Cape in Cape Town, South Africa. He holds a D.Phil in Economics from the University of Oxford.

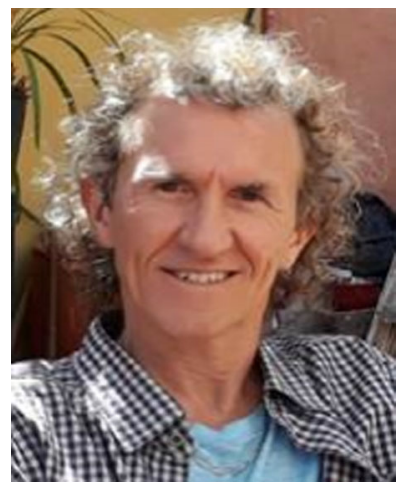

Christophe Béné is Senior Policy Expert at the International Center for Tropical Agriculture (CIAT). Before joining CIAT in 2015, he worked for different research organizations including the Economic Department of the University of Portsmouth in UK, the WorldFish Center in Egypt and Malaysia, and the Institute of Development Studies (IDS) in UK. His work focuses on food security and poverty. He holds a $\mathrm{PhD}$ in Environment and Life Sciences from the University of Paris 6 (France), and a post-graduate Diploma in Development Economics from the School of Development Studies at the University of East Anglia (UK).

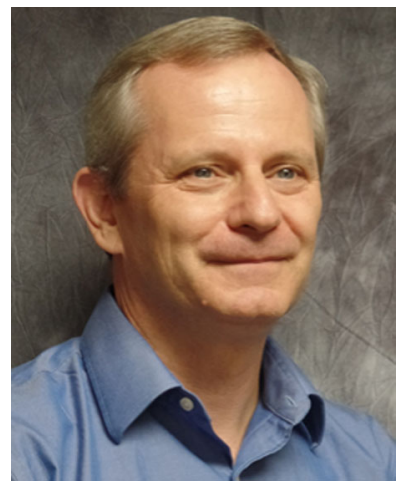

John Hoddinott is the H.E. Babcock Professor of Food and Nutrition Economics and Policy, Cornell University. Before coming to Cornell in 2015, he was a Deputy Division Director at the International Food Policy Research Institute, Washington DC. His research focuses on the causes and consequences of poverty, hunger and undernutrition in low income countries. He holds a D.Phil in Economics from the University of Oxford. 